\title{
Anthropocene or Capitalocene? Two Political Ecological Perspectives
}

Jason W. Moore, editor. Anthropocene or Capitalocene? Nature, History, and the Crisis of Capitalism. Oakland, CA: PM Press 2016. ISBN 978-1-62963-148-6, Price \$21.95. xii+222 pages.

Ian Angus. Facing the Anthropocene. Fossil Capitalism and the Crisis of the Earth System. New York: Monthly Review Press 2016. ISBN 978-58367-609-7, Price \$16.15 (paperback); 978-1-58377-610-3, Price \$95.00 (hardback). 277 pages.

Over the past several years numerous books have appeared that seek—in one form or otherto grapple with the concept of the "Anthropocene". What is distinct about the two books reviewed in this essay is that their respective contributors by-and-large adopt political, ecological, or perhaps more precisely, eco-Marxian perspectives in addressing the Anthropocene concept. However, on the one hand, Jason W. Moore and most of his collaborators, and Ian Angus, on the other hand, adopt different stances on the utility of the Anthropocene concept, with the former group preferring the concept of the "Capitalocene" and the latter preferring to work with the concept of the Anthropocene.

In 2000 the atmospheric chemist Paul J. Crutzen and the marine scientist Eugene F. Stoermer published an article on the Anthropocene in the Newsletter of the International GeosphereBiosphere Programme (IGBP). While various scholars had previously bandied around this term, that article, scarcely more than a page long, has proven extraordinarily influential. In it, Crutzen and Stoermer (2000) propose the naming of a new geological epoch, one which would emphasize the central role played by humanity in shaping the geology and the ecology of the Earth. Later, Crutzen posited the beginning of the Anthropocene as having occurred in 
the late eighteenth century, spurred on by the invention of the steam engine by James Watt in 1784 , thus marking the onset of the Industrial Revolution which subsequently diffused from England to many parts if the world. In due course, fossil fuels, namely coal, oil, and natural gas, would contribute to a dramatic rise in carbon dioxide in the atmosphere, rising from 280 ppm to the current figure of $404 \mathrm{ppm}$. More recently, Crutzen (along with others, particularly Will Steffen and John R. McNeill), have dated the beginning of the Anthropocene to around 1945 , marked by the creation of the atomic bomb and the onset of incredible global economic growth. Conversely, other scholars point to the invention of fire or the development of agriculture as the real starting date of the Anthropocene.

Aside of a heated debate as to the origin point of the Anthropocene concept, various political ecologists, ecosocialists, and neo-Marxian scholars have asserted the term Anthropocene is misleading for a number of reasons, including that it inadvertently-even if unintentionallyimplies that all humans have been equally complicit in contributing to a rise of greenhouse gas emissions, anthropogenic climate change, and an ecological crisis.

The contributors to Anthropocene or Capitalocene? by-and-large adopt this critical stance. In making a case for referring to the "Anthropocene" as the "Capitalocene", Moore, in his chapter titled "The Rise of Cheap Nature", asserts that the deforestation of vast regions that began in Europe under medieval feudalism sped up under capitalism, particularly between 1450 and 1750 when the "greatest landscape revolution in human history" (91) occurred on both sides of the Atlantic. The Capitalocene as a world ecology system ramped up with its reliance on cheap labor and cheap energy, particularly in the form of fossil fuels. In a similar vein, in his chapter, Elmar Alvater, who is well known for his notion of "fossil capitalism," argues that while "it is impossible to give an exact date for the beginning of the Anthropocene" (142), its onset probably "occurred between the beginning of European modernity in Braudel's 'long sixteenth century' [2009], and the industrial-fossil revolution of 
the second half of the eighteenth century" (142). He asserts that with the Industrial Revolution, owners of the capitalist mode of production converted nature into a capital asset. In her chapter titled "On the Poverty of our Nomenclature," Eileen Crist argues that while "Anthropocene exponents have understandable misgivings - about too disruptive a climate, too much manmade nitrogen, or too little biodiversity" (17), the Anthropocene discourse "calls us to the high road of becoming good managers of the standing reserve" (29), a position that is compatible with a green capitalist agenda, one which she rejects. Daniel Hartley, in his chapter "Anthropocene, Capitalocene, and the Problem of Culture," raises an additional problematic in noting that, "as a way of talking about geological changes, the Anthropocene discourse is relatively harmless. Danger arises, however, when geologists enter the political arena, calling for collective ecological intervention on the basis of the Anthropocene" (155). In delineating various conceptual problems associated with the Anthropocene discourse, he notes "Anthropos", or the human, is never clearly defined, but relies on vague, ahistorical terms such as the "human enterprise [attributed to Steffen et al. 2011a, 849]," whereas "a historical conception of humanity, in contrast, would see humans as internally differentiated and constantly developing through contradictions of power and re/production" (155). Christian Parenti seeks to elaborate upon the Capitalocene stance by imploring critical scholars wishing to elucidate the Capitalocene to theoretically grapple with the state, which has historically played a role in seizing portions of the Earth's surface, measuring it, controlling it militarily, legally, and scientifically, and developing communication and transportation networks upon it.

In contrast to most contributors to the anthology, in their chapters, Donna J. Haraway and Justin McBrien adopt new terms beyond those of the Anthropocene and Capitalocene. While Haraway explicitly distances herself from H.P Lovecraft's misogynist racial-nightmaremonster Cthulu, she proposes the term Chthulucene, an awkward term, to refer to an epoch in 
the making and consisting of "ongoing multispecies stories and practices of becoming-with in times that remain at stake, in precarious times, in which the world is not finished and the sky has not fallen-yet" (59). In a somewhat different metaphorical sense, McBrien writes of the Necrocene as an epoch in which capitalism "has produced a Sixth Extinction [Kolbert 2014]" while hoping to "invent new corpses upon which to feast" (134), such as it did in the past with coal and oil.

Anthropocene or Capitalocene? constitutes an effort that moves the Anthropocene discourse to a new level, one that identifies global capitalism as the elephant in the room when it comes to the ecological and climatic crisis and the need to transcend it with a more sustainable world system, although the parameters of an alternative are not explicitly defined. The deeper question is how to shift earth scientists to recognize that the "Capitalocene" describes human impacts upon the Earth's geology better than the term "Anthropocene."

In contrast to contributors to Moore's anthology, Ian Angus (2016) in Facing the Anthropocene advocates working with proponents of the Anthropocene, at least the more progressive ones. He argues that after remaining the exclusive domain of Earth science specialists for nearly a decade, the Anthropocene concept has been adopted by social scientists, humanists, and journalists and has become the focus of three academic journals. Angus also views the Anthropocene concept as a useful organizing tool for ecosocialists, arguing

So the challenge for socialists is not to proclaim the revolution from every street corner, but rather to unite the broadest possible range of people, socialists or not, who agree that the climate vandals must be stopped. We need to work with everyone who is willing to join in fighting climate change in general, and the fossil fuel industry specifically (216). 
He explains that in 2004 a team of earth scientists associated with the International Geosphere-Biosphere Program (IGBP) compiled a report titled Global Change and the Earth System: A Planet Under Pressure (Steffen et al. 2004) which includes "24 graphs - twelve showing historical trends in human activity (GDP growth, population, energy consumption, water use, etc.) and twelve showing physical changes in the Earth System (atmospheric carbon dioxide, ozone depletion, species extinctions, loss of forests, etc.) over 250 years" (Angus 2016, 38). Angus asserts that the report makes an "invaluable contribution to broad understanding of the Earth System" (37) in that it reveals that "every trend line showed gradual growth from 1750 and a sharp upturn from about 1950" (38).

Angus maintains that ecosocialist movements must adopt four principles in order to be successful in their efforts in the Anthropocene: "1. We must be pluralist and open to differing views within the green left" (Angus 2016, 218; original emphasis); "2. We must constantly extend our analysis and program in the light of changing political circumstances and scientific knowledge" (219; original emphasis); "3. We must be internationalist and antiimperialist" (220; original emphasis); and "4. We must actively participate in and build environmental struggles, large and small" (221; original emphasis). While his position is one that certainly aligns with the ecosocialist and green left, and he is fully cognizant that most leftists prefer the term Capitalocene to Anthropocene, he maintains that substituting the latter for the former is a "category mistake" (232). He explains that "capitalism is a 600-year-old social and economic system, while the Anthropocene is a 60-year-old Earth System epoch [that] will continue long after capitalism is a distant memory" (232). At least, that is his hope. As for myself, while the Anthropocene concept may foster dialogue between earth scientists and other scholars, I remain skeptical whether the concept explains anything that we have not known all along, namely that human activities, particularly those that fall under the rubric of global capitalism, have had and continue to have a profound impact on the Earth System. 
After all, while some scholars have embraced the Anthropocene concept or some variant of it with gusto, others have remained relatively indifferent to it. The deeper question is how do we humans learn to live in harmony with each other and with nature as we push further and further into an age characterized by social disruption and ecological and climatic crises. In my own experience, while many earth scientists, including particularly climate scientists, are aware that humans are in a metabolic rift with nature, something that Marx and Engels observed (Foster 2000), most of them are not willing to recognizeglobal capitalism as the principal driver of the ecological and climatic crisis in the modern era.

\section{References}

Crutzen, P. J. and E. F. Stoermer. (2000). “The Anthropocene.” Global Change Newsletter 41:17-18.

Foster, J.B. (2000). Marx’s Ecology. New York: Monthly Review Press.

McNeill, J. R. and P. Engelke. (2014). The Great Acceleration: An Environmental History of the Anthropocene since 1945. Cambridge, MA: Belknap Press of Harvard University Press.

Steffen, W., A. Sanderson, P. D. Tyson, J. Jäger, P. A. Matson, B. Moore III, F. Oldfield, K. Richardson, H. J. Schellnhuber, B. L. Turner and R. J. Wasson. (2004). Global Change and the Earth System: A Planet Under Pressure. Heidelberg: Springer-Verlag. 


\section{University Library}

\section{- M M N E R VA A gateway to Melbourne's research publications}

Minerva Access is the Institutional Repository of The University of Melbourne

Author/s:

Baer, $\mathrm{H}$

Title:

Anthropocene or Capitalocene? Nature, History, and the Crisis of Capitalism

Date:

2017-06-01

Citation:

Baer, H. (2017). Anthropocene or Capitalocene? Nature, History, and the Crisis of Capitalism. HUMAN ECOLOGY, 45 (3), pp.433-435. https://doi.org/10.1007/ s10745-017-9895-4.

Persistent Link:

http://hdl.handle.net/11343/283256 